\title{
An Annotated Archive of Entangled European Feminist History: The Union of Turkish Women, the Second Balkan Conference and Cécile Brunschvicg's Visit to Balkan Feminists (1923-1935)
}

\author{
Asli Davaz ${ }^{1 *}$
}

Published: September 8, 2020

\begin{abstract}
This article will examine the role of women in the Second Balkan Conference which took place in Istanbul in October of 1931, and further examine if any of these women interacted or had been in cooperation prior to the conference. Two years following the Conference, Cécile Brunschvicg went on a study tour to Yugoslavia, Greece, Turkey, Bulgaria and Romania in August and September 1933. She subsequently published in La Française a report of this trip through a series of articles titled 'Interviews with Eastern European Feminists' in which she focused on the advancement of the women's movement. This article will also focus on the role of the Union of Turkish Women over the course of the period from 1923 to 1935.
\end{abstract}

Keywords: Second Balkan Conference, Cécile Brunschvicg, Eastern European Feminists, Union of Turkish Women, Little Entente of Women, Twelfth Congress of the International Women's Alliance

\section{INTRODUCTION}

As an archivist of women's history who has been working in this capacity for over 30 years, my main aim as a feminist researcher is to bring to light documents and primary sources connected to this topic. I found the sources utilised for this article while researching for a book on the international women's movements (Davaz, 2014). For that project, I accessed at the Bibliothèque Marguerite Durand ${ }^{1}$ (Marguerite Durand Library) (1931) the archive of the weekly journal La Française ${ }^{2}$ (1906-1940) published by Cécile Brunschvicg (1877-1946), who was the editor of the journal and an important suffragist and delegate at the Twelfth Congress of the Alliance Internationale pour le Suffrage et l'Action Civique et Politique des Femmes (International Alliance of Women for Suffrage and Equal Citizenship) (IAWSEC), ${ }^{3}$ which took place in Istanbul in 1935. Brunschvicg travelled to the Balkans and wrote a series of articles about Eastern European feminists in La Francaise. The journal also contains information about the rights Turkish women acquired in the new Republic and published news about the Twelfth IAWSEC Congress, as well as an article by Necile Tevfik (1911-1964), titled 'The Turkish Women of Today' (Tevfik, 1935). La Française became an important source of information about the activities of the international women's movements and issues brought forth during the Twelfth Congress. Overall, this project offered me the opportunity to uncover the views of Western feminists about the women's movements in the Balkans and the Middle East, regions that were under Ottoman control for centuries, as well as the Far East and Turkey.

Another institution I benefited from was the Atria Institute on Gender Equality and Women's History (1935). The institute sent me a copy of the letter Necile Tevfik wrote to Rosa Manus (1881-1942) announcing the dissolution of the Union of Turkish Women (1924-1935) (Türk Kadn Birliği, TKB) and confiding her true feelings about the situation ${ }^{4}$. I was able to access all of the Jus Suffragii (1906), the periodical published by IWSA, IAWSEC

${ }_{1}^{1}$ The Marguerite Durand Library opened in 1931, when Durand donated her documents to the Paris Municipality. . Further information is found here: https:/ /www.paris.fr/equipements/bibliotheque-marguerite-durand-bmd-1756

2 This journal was founded by feminist journalist and activist, Jane Misme (1865-1935).

${ }^{3}$ Officially established in 1904 as International Woman Suffrage Alliance, IWSA in 1926, the organisation was renamed the International Alliance of Women for Suffrage and Equal Citizenship, IAWSEC or simply IAW (De Haan, 2017: 507).

${ }^{4}$ The IAWSEC Press Bureau Secretary for the Twelfth Congress was Louisa K. Fast, and she had correspondence with Necile Tevfik regarding the preparation of the Congress and the relations with the Turkish Press. Nermin Muvaffak was also working

${ }^{1}$ Researcher; a founding member and currently president of the Women's Library and Information Centre Foundation (WLICF), Istanbul, TURKEY

*Corresponding Author: adavaz@otoanaliz.net; denizaslidavaz@gmail.com 
at the Gerritsen Digital Collection. I found an additional and important source at the Center for Middle Eastern Studies at the University of Chicago which has all the issues of L'Egyptienne (1925-1940), the periodical of the Egyptian Feminist Union. Reading through it, I came to appreciate how closely the journal had been following Turkish activists, Nezihe Muhiddin (1889-1958), Necile Tevfik, Lâtife Bekir (1899-1952), the UTW (Union of Turkish Women), Eastern European feminists, the Balkan Conferences, the 1935 Congress of the IAWSEC in Istanbul, and the women's movement in Turkey.

Overall, it was difficult to follow the international relations of the UTW as there are no known existing archives of this organisation ${ }^{5}$. This is why I directed my efforts to other sources. I consulted these primary sources to investigate the relations of the UTW with international women's movements during its short-lived period of international activities and my starting point was the archives of the IWSA, IAWSEC, the only international organisation of which the UTW was a member. I located the archives of the IWSA and IAWSEC in four institutions that house women's archives: Atria Institute on Gender Equality and Women's History in the Netherlands, the Sophia Smith Collection in the USA, the Women's Library (1926) in London, UK and Bibliothèque Marguerite Durand ('Marguerite Durand Library') in France. These four archives contain letters sent by the UTW officials to IWSA, IAWSEC officials and innumerable documents related to the Twelfth Congress in Istanbul.

The Necile Tevfik papers in the Women's Library (1990) in Istanbul are a small collection and do not contain documents of her private life. Yet some important gems are found there, such as a letter by the Dutch suffragist Rosa Manus expressing her feelings about the dissolution of the UTW on the 10th of May, 1935. Tevfik's papers also preserve her notes on the Twelfth Congress of the IAWSEC and about the Balkans in her own handwriting. The archive of Necile Tevfik arrived at the Women's Library in 1999 and only then did her name and activities become visible. My investigation of her archive unearthed facts about her membership in the Executive Committee of the UTW, about her participation as a delegate of that organisation in the 1935 Congress of the IAWSEC, and about her work as a journalist during the Second Balkan Conference. Her archive also contains documents about the Romanian women's delegation to the Second Balkan Conference.

As a feminist researcher writing on international women's movements, of chief importance to me is the international character of the sources I use. Official documents concerning the Second Balkan Conference provide key facts on the participation of Eastern European feminists and indicate the contents of the motions they presented. State and official documents still lack in documenting the full scope of women's history and the international women's movement. Sources created by women are thus essential and throughout this paper I will refer to the women's documentary heritage.

In this paper, I will begin with a brief discussion of the nature of the international relations of the UTW, as well as its relation with the Little Entente of Women (1923), which aimed to create a regional platform among women of Central and Eastern European countries in order to achieve full gender equality. I trace new evidence regarding the participation of Eastern European women in the Second Balkan Conference held in Istanbul in 1931. I start with their presence at the First Balkan Conference and explore the nature of the women's expectations and the contents of their motions. Finally, I follow Cécile Brunschvicg through her study tour in five Balkan countries and her encounters with the Eastern European feminists.

\section{THE UNION OF TURKISH WOMEN AND ITS INTERNATIONAL RELATIONS (1923- 1935)}

The struggle of the Western suffragists was frequently featured in Kadmlar Dünyast ('The Women's World'), ${ }^{6}$ a journal of the Müdafâa-i Hukuk-ı Nisvan Cemiyeti (Association for the Protection of Women's Rights) (1913) (Çakır, 1994), one of the most important associations in the Ottoman women's movements, founded by the first Ottoman feminists. However, during that time women's interest in achieving political rights remained within the boundaries of the journal. In contrast, foreign women living in the Ottoman Empire such as authors, journalists, travellers and the wives of ambassadors and consuls took great interest in the organisation and the journal, and foreign female journalists introduced the journal to their Western counterparts and sent articles to their women's periodicals.

with them. Later, Katherine Bompas also joined the IWSA Press Bureau. The members of the Press Bureau of the UTW were Efzayiş Suat, Leman Fuat, Mihri Hüseyin, Necile Tevfik.)

${ }^{5}$ For this purpose I used the following publications: newspapers and journals published in Turkey between 1924 and 1935 , such as Cumburiyet ('The Republic') (1924-today), Kurun ('Centuries') (1934-1939), Aksam ('The Evening') (1918-today), Son Posta ('The Last Post') (1930-1960), La Turquie Kemaliste ('The Kemalist'Turkey')(1933-1949) and Türk Kadin Yolu ('The Turkish Women's Path') (1925-1927), the official journal of the UTW at the Women's Library (1990) in Istanbul and some documents which were found in archival centres abroad such as the Sophia Smith Collection (1942) and the Women's Library (1926) in London.

${ }^{6}$ Kadinlar Dünyası was the journal of Müdafâa-i Hukuk-1 Nisvan Cemiyeti. 208 issues were published between 1913 and 1921. 
Before the establishment of the Republic in 1923, the Ottoman women's movement did not leave an important legacy to the women of the Republic in the area of international relations. Still, in 1920, Azize Kibrisli represented Turkey at the Geneva Congress of the IWSA. She was sent as an official delegate of the Ministry of Foreign Affairs. It is not very clear if she later became a member of the UTW but she was present at a meeting held by Nezihe Muhiddin on February 17th 1924 . The speech she delivered in French at the Congress was published in its entirety in Jus Suffragii (Keibrizli, 1920: 164). The 1923 Rome Congress of the IWSA had no representative from Turkey. However, the application of the UTW for the membership of IWSA (which then turned into IAWSEC) was favourably voted for at the 1926 Paris Congress. It was only at this organisation's 1929 Berlin Congress that UTW sent Efzayiş Suat as an official delegate. Examining the Türk Kadın Yolu ('Turkish Women's Path') journal published by the UTW, it becomes evident that Nezihe Muhiddin was the key figure who initiated work in this field. During her editorship of the journal, she published her correspondence with the IAWSEC under the title 'Dünya Kadın Postası' ('International Women's Post'). Muhiddin published news about struggles for full equality in political rights and citizenship, and reported on world-wide developments on these issues. Women who knew foreign languages, such as Efzayiş Suat, worked with Muhiddin to develop international connections. According to reports in Türk Kadin Yolu and Jus Suffragii, representatives of the IAWSEC came to Istanbul from time to time to keep in touch with the Turkish women's activists. The American Emily Rieder ${ }^{7}$ and Anne Stès were the most important figures to promote relations between the two organisations. Foreign women living in Istanbul also helped to promote these relations. The already-mentioned column with international news featured in the journal Türk Kadm Yolu published information about the activities and specifically about the congresses and decisions of IWS $A$, as well as correspondence between Nezihe Muhiddin and Margery Corbett Ashby, President (1923-1946) of IWSA/IAWSEC. Unofficial relations with women in Turkey were first established at the preliminary Conference of the IWSA in Washington, DC, in 1902 and Turkey was represented by a U.S. citizen, Florence A. Fensham. Fensham came to Istanbul as a teacher of religion at the American College for Girls. Little is known about how and why she was invited to this Congress. After joining the IAWSEC, the UTW participated in the Berlin Congress of 1929 and the Marseille Conference of 1933. These international contacts ended with the dissolution of the UTW in 1935. According to Rieder's brief report published in Jus Suffragii, before its dissolution, the UTW was a very active organisation with approximately three hundred members (“Turkey", 1925).

Turkish feminists' efforts to get involved in the international women's movement began slowly. Although, these efforts were not at the top of the UTW activists' agenda, the Union's international relations gradually reached a higher level and the first feminists of the Republic chose to be part of the above-mentioned feminist network. The UTW was actively involved in the international women's movement between 1926 and 1935, with the Twelfth Congress of the IAWSEC in Istanbul (1935) as the highest point. But on 10 May, 1935, the UTW was also dissolved and erased from the stage of the international women's movement. Ultimately, the dissolution of the UTW did not have broad repercussions on the international women's movement.

Many articles about Turkish women and the Union of Turkish Women between 1920 and 1935 were published by Jus Suffragii. From June 1934 until the end of 1935, the UTW and Turkey were frequently on the agenda. One reason for this coverage was the admission of the UTW to the IWSA during the 1926 Paris Congress. In a sense, the UTW conducted its international relations with the women's movement through Jus Suffragii. Although the UTW had international relations on its agenda, it did not attend any congress other than those of the IWSA/IAWSEC.

Seniha Rauf represented the UTW at the Balkan Women's Conference for Peace in May 1931 in Belgrade and delivered a speech underlying the importance of permanent peace in the Balkans. The speech was published in its entirety in Jus Suffragii ("Turquie-Déleguée: Mme. Seniha Rauf”, 1931). From June 1934 onwards, a number of news items about the Twelfth Congress, planned for Istanbul in 1935, began to appear in the journal. In June 1934, the front page of the journal was devoted entirely to this Congress ("Twelfth Congress: Istanbul, 18-25 April, 1935”, 1934). It had the announcement of the Congress with a photo of Lâtife Bekir Çeyrekbaş1, ${ }^{8}$ the president of the Executive Committee of the Union of Turkish Women. From October 1934 to March 1935, all information about the Congress appeared and the detailed programme of the Congress was published in the November 1934 issue. The April 1935 issue featured a message by Çeyrekbaşı and her biography.

During this period, Balkan women established communication networks 'to fight their marginalization within the international women's organizations' and better defend their interests within the region (Daskalova, 2008). Czechoslovak, Romanian and Yugoslav politicians came together after the First World War with the aim of

\footnotetext{
${ }^{7}$ Letter written by Emily Faber Rieder to Nezihe Muhiddin on 27th of June 1925, Kadn Yolu, No. 2, 23 July 1341 [1925], s. 31 (Ateş, 2009, s. 106).

${ }^{8}$ She was one of the first women elected to the Istanbul Municipal Council (1933) and elected MP of Izmir in 1946 on the candidate list of the Republican People's Party with 16 other members.
}

(C) 2020 by Author/s 
defending their independence and anti-revisionism, creating an (male) alliance called the Little Entente ${ }^{9}$ in 1920. The Little Entente of Women (LEW, 1923) was formed during the IWSA Rome Congress at the suggestion of Polish physicist Justyna Budzińska-Tylicka (1867-1936) and Romanian feminist activist Alexandrina Cantacuzino (1876-1944), with the participation of women activists from Yugoslavia, Bulgaria, Romania, Greece, Poland and Czechoslovakia. Establishing permanent peace in the countries of Central and Eastern Europe and creating a platform for exchange of ideas among women in order to achieve full gender equality were among the aims of this Entente. Balkan women were dissatisfied with the attitude of the Western feminists and believed that if the Western-based feminist movement were shifted to the east of Europe and a 'Balkan identity based on gender' was created, women of the region would be able to defend their own interests better (Psarra, 2007).

One of the most interesting developments at the LEW Prague Congress in 1927 was the discussion on open doors to women's organisations from Turkey, Albania and Bulgaria, despite strong opposition from Cantacuzino. In the end, these countries were not included in the network. The Entente convened for the last time in 1929 in Warsaw. At a time of rising nationalism, Balkan women found it difficult to maintain independent policies and drifted towards the political line of their governments. Recent research by several historians on the LEW (Bucur, Nationalism and Feminism in Interwar Romania: Alexandrina Cantacuzino and the Little Entente, 2019) has shed additional light on the history of this and other regional women's organisations and initiatives, both Balkan and East European (Daskalova, 2018).

\section{WOMEN AND THE BALKAN CONFERENCES OF THE 1930s}

The First Balkan Conference was welcomed by the women's movements in the region and their newspapers and journals. Balkan unity was a great hope for the politically active women who suffered during the two Balkan Wars (1912-1913) and the First World War (1914-1918). The main agenda of the First Balkan Conference, convened in Athens on October 5-12, 1930, was permanent peace ("Première Conférence Balkanique", 1930) and the establishment of an economic and political union of the Balkan countries. The conference was covered widely in O Agonas tis Gynaikas ('Women's Struggle') (1923), the fortnightly publication of The Union of Greece for Women's Rights. The editor of this journal, Avra Theodoropoulos (1880-1963) ${ }^{10}$, played an important role during the conference. Although women delegates were a minority among the total number of delegates from Albania, Bulgaria, Greece, Romania, Turkey and Yugoslavia, they participated actively in the conference. Among them were the president of the Alianza ženskih pokretov Jugoslavije (Union of Women's Movements of Yugoslavia) Militza Bogdanovic as well as the feminist Alojzija (Lojzka) Štebi (1883-1956) ${ }^{11}$, Emine Toptani - the president of the Union of Albanian Women and from Greece, Callirhoe Parren (1859-1940), Maria Svolou (1892?-1976), Alexandra Thiacakis, and Helen Sifnaiou ("Première Conférence Balkanique", 1930).

Five months before the Second Balkan Conference, the Balkan states adopted the proposal of the women's organisations to come together and identify areas of cooperation. The Yugoslav women organised a conference entitled Balkan Women's Conference for Peace in Belgrade on 20 May 1931. The conference was attended by representatives of women's associations from Greece, Bulgaria, Turkey and Romania, as well as representatives of university-educated women and all feminist organisations in Yugoslavia. Congress president Theodoropoulos, in a report on the common working methods of women in Balkan countries, recommended the establishment of a Union of Balkan Women to ensure coordination. At the Conference it was decided that the national delegations to the Balkan Union should form a women's committee, and it was proposed that a joint publication be established to collect women's news in these countries. Women university graduates also made a number of interesting suggestions: organising a simultaneous Balkan week in individual Balkan countries; faculty, museum, and library exchanges; opportunities for female scholars to travel and present at regional conferences; establishing libraries to promote the culture of Balkan countries; and translating folklore books to include various traditions in each country's curricula.

At the end of this conference, they aimed to create a common Balkan consciousness and to draw attention to women's issues. Women from Bulgaria, Romania, Turkey, Yugoslavia and Greece signed a three-point resolution: an active role would be taken in the sub-working groups of the Balkan Conference, an inter-group women's

\footnotetext{
${ }^{9}$ After World War I, Hungary and Bulgaria were dissatisfied with the treaties they had signed and maintained a revisionist attitude and policy towards these treaties. Hence an alliance was formed with Czechoslovakia, Romania and Yugoslavia, under the leadership of France, based on mutual solidarity (Akandere, 2004: 253).

${ }_{10}$ Avra Theodoropoulos (1880-1963) was one of the leaders of the Greek women's movement, feminist writer, suffragist, musicologist, music critic, theatre and story writer. In 1923, she was among the founders of the Little Entente of Women. Theodoropoulos attended the Congress of Eastern Women, one of which convened in Damascus in 1930 (Boutzouvi, 2006). 11 Alojzija Štebi (1883-1956), a prominent figure in the Serbian, Croatian, and Slovenian women's movements, was known for her struggle for women's rights and social issues both nationally and internationally (Verginella, 2006).
} 
committee would be formed, and the number of women representatives would be increased in the national delegations. The signatories on the text of the resolution were Seniha Rauf on behalf of Turkey and Catherine Cerkez Atanasiu on behalf of Romania. Bulgaria was represented by a large group of women, among them Dimitrana Ivanova, J. Bozvelijeva, and Dr. D. Mihailov. On behalf of Greece A. Theodoropoulos, A. Papadimitriju, C. Georgijadès, A. Salogheropoulos, M. Tanopoulos, E. Karidi, and K. K. Marmaki participated. Yugoslavia was respresented by Alojzija Štebi, Leposava Petković, Mira Kočonda-Vodvorka, Milena Atanaković, and P. Albala.

The Second Balkan Conference was held in Istanbul on October 19-26, 1931 at the Yildız Palace. The Turkish government undertook extensive technical preparation at the Yildı Palace for the conference, such as laying telephone lines, connecting electricity and allocating special rooms for the attending representatives of the press. Two special postage stamp series commemorating the event were printed in London and released during the Conference.

Four years later, the same Palace was used for the Twelfth Congress of the IAWSEC, and at that time the technical preparations and the infrastructure established were far more comprehensive. The preparations undertaken for the Twelfth Congress aimed to promote and publicise the suffrage rights recently given to women in Turkey and other rights of equality extended to them by the newly adopted Turkish Civil Law. For the 1935 Congress, these preparations included the printing of 1.5 million postage stamps issued as 15 special series. While the stamps published for the Balkan Conference were distributed and sold only in Turkey, those published for the Congress of the IAWSEC were bought by organisations and women of the fifty member states and were distributed internationally. In comparing the two events, it is evident that the Turkish government invested far more in the public relations activities for the women's congress of 1935.

Countries participating ${ }^{12}$ in the Second Balkan Conference were Turkey, Albania, Bulgaria, Romania, Yugoslavia and Greece. The three official female delegates from Romania were Cantacuzino ${ }^{13}$, the president of Consiliul national al femeilor române ('National Council of Romanian Women'), Calypso Botez (1880-?) ${ }^{14}$, the president of Asociatia femeilor române ('Romanian Women's Association'), and Catherine Cerkez Atanasiu, the General Secretary of the National Council of Romanian Women. The remaining seven women in the Romanian delegation were on the substitute delegates list and carried no official responsibilities, although they did work actively. During the conference, for instance, Zefira Colonel Voiculescu ${ }^{15}$ and Ortansa Satmari met with Turkish journalist and women's activist Necile Tevfik ${ }^{16}$. Other Romanian female delegates ${ }^{17}$ also attended meetings with various members of the UTW.

\footnotetext{
12 For the names of the delegates and alternates of the Congress see Ilème Conférence Balkanique (1932, 7-17).
}

13 Alexandrina Cantacuzino (1876-1944) came to Istanbul twice, the first time to the Second Balkan Conference in October 1931 and then to the Congress of the IWSA in 1935. One of the leading feminists of her country, she spent the last fifteen years of her life working with a broad variety of women's associations. With her nationalist and feminist views, Alexandrina Cantacuzino became one of the most important and most controversial women in Romania, with an active role in the international women's movement, especially between the two world wars. She supported the social development of women with her contemporary views, albeit in favour of traditions (Cheşchebec, 2006). For further information see Roxana Lucia Cheşchebec, "The "Unholy Marriage" of Feminism with Nationalism in Interwar Romania: The Discourse of Princess Alexandrina Cantacuzino,'

http://archeologia.women.it/user/quarta/workshops/european9/roxanaches9.htm. (Accessed 18 June 2019).

${ }^{14}$ Calypso Botez (1880-?) was one of the first woman elected member of the Bucharest Metropolitan Municipality and also a militant activist of the National Peasant Party. Together with other feminist activists, including Ella Negruzzi, she struggled to fundamentally change the political, economic and social status of women. She participated in the 1923 Rome, 1926 Paris, 1929 Berlin, and 1935 Istanbul congresses of the IWSA (Bucur, 2006).

${ }^{15}$ General Secretary of National Orthodox Romanian Women's Society. On the personal card, her name was mentioned as Zefira Colonel Voiculescu.

${ }^{16}$ Tevfik (1911-1964) started writing in the fields of literature and cinema at a very young age, published a story book called Istersen Okuma, and sold some of her scripts to film companies in Hollywood. She served as a member of the Executive Committee of the Turkish Women's Union between 1932 and 1935. She actively participated in the preparatory work for the Twelfth Congress of the IAWSEC in Istanbul. She was one of the official delegates of Union of Turkish Women. Tevfik, who worked for the newspapers La République and Ikdam between 1932 and 1936, began working in Zaman and Yeni Sabab in 1944. During the same period, her articles were published in the French-language newspaper Le Journal d'Orient based in Istanbul. Throughout her life, she worked for women's struggle for equality and freedom, and her writings on women's rights have also been published in many international women's magazines. A report by Tevfik in French on the marital status of modern Turkish women was published in the magazines La Française, Revista Feminină, L'Egyptienne, Jus Suffragii and Le Droit des Femme. Tevfik was one of the founding members of the Turkish Women's Union Administrative Committee and the Turkish Women's Union and was active in the women's movement of the period. She was also among the founders of the second Turkish Women's Union, which was re-established in 1949 (Davaz, 2019).

${ }_{17}$ Only the surnames Voiculescu and Satmari are mentioned in the official reports of the Second Balkan Conference as alternate delegates. Their names were written on the personal cards that they gave to Tevfik during the conference. In addition, 
The Albanian delegation consisted of eight participants but no women. Dimitrana Ivanova $(1881-1960)^{18}$, the president of the Bulgarski Zhenski Suiuz ('Bulgarian Women's Union') was the only woman in the Bulgarian delegation, led by the president of the parliament. The Yugoslav delegation had fifteen members and only one woman, Militza Topalovic, who represented the Yugoslav branch of the Women's International League for Peace and Freedom. ${ }^{19}$ The Greek delegation was represented by twenty-eight members, including Alexandra Thiacakis and M. Tanopoulos, who were the representatives of unnamed women's associations in Greece.

Upon approval by the Turkish government of their application to participate at the conference by, the Executive Committee of UTW met on 13 September 1931 and designated Lâtife Bekir Çeyrekbaşı, Lâmia Refik, Efzayiş Suat and Seniha Rauf as delegates. At the end of the third day of the Conference on 21 October, the UTW organised a reception for the foreign women delegates at the Türk Ocağı ('Turkish Hearths'). The reception was attended by Cantacuzino, Voiculescu, Botez, Satmari, Circassian, Gika, Konstantinesko, Kiomak, KurutezeskoStork, and Helene Pribeji from Romania; Dimitrina İvanova from Bulgaria; Thiacakis and Tanopoulos from Greece; and Topalovic from Yugoslavia, as well as most women delegates who were in Istanbul for the Conference (Akandere, 2004: 260-261).

Women delegates at the Second Balkan Conference submitted many reports to different commissions. ${ }^{20}$ Even though I could not reach the reports presented by the Bulgarian women at the conference, there is information regarding the three proposals ${ }^{21}$ submitted by the National Council of Romanian Women, which was found among Tevfik's private documents. The three page document is handwritten in French, and is titled 'Conseil National des Femmes Roumaines - Conférence Balcanique à Constantinople du 20-26 Octobre 1931' 'The National Council of Romanian Women - Balkan Conference, Constantinople, 20-26 October 1931'). The most significant item in the document recommended increased economic cooperation among the Balkan countries, as well as the adoption of a single currency. It also recommended the establishment of a customs union to strengthen the unity of interests as a Balkan bloc and to withstand the international competition which put increasing pressure on the Balkan economies. The third recommendation, about education, suggested that middle and high-school students be provided with discounted rail tickets and free accommodation in each country so that they may visit the key centers of the Balkan Union.

Unfortunately, I could not locate any further information on whether or not the National Council of Romanian Women submitted a report specifically on women's issues. It is clear, however, that on 25 October 1931, Cantacuzino, a member of the Political Rapprochement Commission, submitted a proposal to the Conference Assembly on Women's Laws in the Balkans. She also raised the issue of women's nationality, an important agenda for international women's organisations at the time ("L'activité de nos soeurs roumaines", 1931).

In the same session, Thiacakis presented her report on the situation of women in Greece and in the Balkans. She emphasised that the social rights achieved by women in Turkey constituted an example to the whole world and were appreciated by all women and thus discussed and commended worldwide at women's congresses and conferences (Akandere, 2004: 285).

among Tevfik's private papers is a personal handwritten card belonging to Zefira Colonel Voiculescu, found in an envelope with the title 'IIème Conférence Balkanique Istanbul', and 'Madamoiselle Necile Tevfik, Journaliste' (Ms. Necile Tevfik, journalist). The card itself consists of the printed name of Zefira Colonel Voiculescu, above a second line reading 'Bucureşti' (Bucharest). On the back of the card, the following names are listed in handwriting: Princess Alexandrina Gr, Calypso Botez and Ortansa Satmari. We may therefore assume either that this personal card was given to Tevfik at the reception held by the UTW on October 21 at the conference as Tevfik was a journalist in the 1930s and could have attended in this capacity (Document 80, Necile Tevfik Private Papers, Private Archives Collection, The Women's Library and Information Center Foundation-Istanbul).

${ }^{18}$ Ivanova (1881-1960) was a teacher, journalist and feminist activist. She was elected as a member of the Executive Board of the IAWSEC at the 1935 Istanbul Congress. After the First World War, Ivanova devoted herself to activism and was the editor-in-chief of the Bulgarian Women's Union newspaper Zhenski glas ('Women's Voice'), where she regularly wrote. From 1926 to 1944, when the communist regime was established, she was the president of the country's largest and most recognised women's organisation, the Bulgarian Women's Union (Daskalova, 2006).

${ }^{19}$ The League was founded by members of the IWSA who did not find the political stance on peace sufficiently determined and radical and left the Union to establish a new organisation in 1915.

${ }^{20}$ The subcommittees working at the conference were: Organisation Commission, Political Rapprochement Commission, Intellectual Rapprochement Commission, Economic Rapprochement Commission, Transportation Commission, Hygiene and Social Policies Commission. In addition, the conference was followed by one representative from the League of Nations and the Carnegie Endowment for International Peace, and two representatives from the International Peace Bureau. The conference started on 19th October at 16.00 and ended on 26th October with the return of the delegation from Ankara (IIème Conférence Balkanique, 16-17, 21-22).

${ }^{21}$ Document 24, Necile Tevfik Private Papers, Private Archives Collection, The Women's Library and Information Center Foundation-Istanbul. Also see Davaz (2019). 
Among the women reporting to the commissions were representatives of the UTW; Efzayiş Suat submitted a report entitled the 'Legal Status of Women' (IIème Conférence Balkanique: İstanbul-Ankara, 19-26 Octobre 1931, 1932) in the 'Hygiene and Social Policies Commission' session (Akandere, 2004: 265). The report suggested that the social reforms introduced in Turkey should be adopted and implemented in other Balkan Union countries as well. In her report, Suat also discussed the issue of prostitution. She stated that the Ministry of the Interior has started a serious struggle regarding prostitution in 1930 and that those who engaged in trafficking white women would be punished heavily. She believed that with these measures, prostitution would decrease. However, she also pointed out that if the Turkish society wanted to achieve full success men had to adopt high moral values. She ended her speech by suggesting that the Balkan countries should establish sub-commissions to deal with social problems, that they should organise surveys, conduct social research, and take all necessary measures in this direction by publishing the results obtained. She also discussed in detail the integration of women into working life and the problems of women's working conditions.

The Yugoslav delegate, Dr. Militza Bogdanovic, working with Suat within the 'Hygiene and Social Policies Commission', addressed the conference on a different topic. According to her, it was necessary to establish common structures in the Balkan countries, primarily economic and cultural, and to ensure free movement within these structures so that a balance could be achieved. Bogdanovic proposed that labor laws should be established, visas between Balkan countries should be abolished, women and children should be protected by special laws and common infrastructures should be created for all kinds of institutions, including trade unions, employment agencies, insurance and social security, enabling these institutions to work in harmony and coordination among Balkan countries (IIème Conférence Balkanique, 1932).

During the session of the 'Intellectual Rapprochement Commission', delegates from Albania, Bulgaria and Turkey focused on co-operation between the Balkan countries. Turkey, along with the Romanian delegates, also underlined the necessity of cooperation between official publications. The Yugoslav delegation, whose name is not included in the official documents, presented a report on efforts to bring Balkan countries closer together.

Balkan feminists attending international congresses were greeted with interest by the Western European suffragists and the members of the IAWSEC visited Romania, Bulgaria, Greece and Turkey. ${ }^{22}$ One of the most important journals of the international women's movement, La Française, reported on developments in the Balkans and Cécile Brunschvicg (1877-1944), editor-in-chief, and Germaine Malaterre-Sellier (1889-1967), a regular contributor, prepared a series of articles on women's movements after their two study tours to the region following the Second Balkan Conference.

\section{CÉCILE BRUNSCHVICG'S STUDY TOURS TO YUGOSLAVIA, GREECE, TURKEY, BULGARIA AND ROMANIA (1933)}

From 1924 onwards, Cécile Brunschvicg 23 , one of the key figures of the French feminist movement, was the editor in chief of the weekly newspaper La Francaise and wrote extensively on women's struggles in France and specifically on the struggle for equal rights between 1906 and 1946. Other women who contributed to the newspaper included Maria Vérone (1874-1938), Germaine Malaterre-Sellier, Avril de Sainte-Croix (1855-1939), Rosa Welt-Straus (1856-1938), the Egyptian feminist leader Huda Sha'arawi (1879-1947), and the Czech feminist activist Františka Plamínková (1875-1942).

Brunschvicg was in the delegation of the French Radical Party ${ }^{24}$ that was headed by Edouard Heriot and that visited Yugoslavia, Greece, Turkey, Bulgaria and Romania from August-September in 1933. Following this Balkan tour ${ }^{25}$, Brunschvicg wrote five articles for the journal La Francaise under the rubric 'Interviews with Eastern European Feminists'. Here she attempted to put together information regarding women's movements in the region and tried to understand the problems of feminists in societies that had lived under Ottoman rule for several centuries. Brunschvicg considered the political and economic situation in the region a cause for concern among western European countries as a whole, as well as for the French women in particular. In Yugoslavia, Brunschvicg

${ }^{22}$ La Française published news about Turkey and Turkish women from time to time and gave regular information about the 1935 Congress. Moreover, the journal published on its front page Tevfik's article about the contemporary situation of women in Turkey (Tevfik, 1935).

${ }^{23}$ Cécile Brunschvicg (1877-1946), one of the key figures of the French feminist movement along with some women, joined the Radical Party, which opened its doors to women, in 1924 and was among the ten women appointed to the party's board in 1929. At the end of the Second World War, she was one of the rare first-generation feminists to witness women's right to vote (Davaz, 2014).

${ }^{24}$ Founded in 1901 and dissolved in 2017.

${ }^{25}$ Here I am using 'study tour' because Brunschvicg herself is using it. She planned this trip with the official delegation of the French Radical Party because she wanted to write this series of articles about Balkan women's movements and she calls these visits a study tour. 
met with Milena Atanaković and Leposava Petković, two of the most influential interwar feminists, and attended a meeting of the Women's National Council in Belgrade. The Yugoslav women were engaged in a struggle for political rights and economic equality, with Atanaković as a Head of Department responsible for mothers and children at the Ministry of Health and Social Affairs. There were other women with important positions in the state bureaucracy, such as Zorka Simić, the director of the Belgrade National Museum, and Petković, an inspector of the State Rail (Brunschvicg, 1933a).

The second stop in Brunschvicg's tour of Eastern Europe was Greece in August of 1933 (Brunschvicg, 1933b). Over several hot days, she met Studitis, the General Secretary of the National Council of Greek Women, and Theodoropoulos, the President of the Syndesmos gia ta Dikaiomata tis Gynaikas (League of Women's Rights), ${ }^{26}$ who both travelled to Athens to meet her. Due to her limited time in Greece, Brunschvicg was not able to visit other women's organisations. According to the reports obtained by Brunschvicg, the most important association established by Greek women in the First World War was the Patriotic Association for the Protection of Children ${ }^{27}$ which later changed its name in 1915 to the Union of Greek Women. ${ }^{28}$ This charity association was organised throughout Greece, providing assistance to pregnant women and new mothers. Under the presidency of Theodoropoulos, the League of Women's Rights was the association that struggled most ardently for women's suffrage rights. This association was also a member of the IAWSEC and one of its aims was to work for the establishment of long-lasting peace in the Balkans.

Brunschvicg reported that the League of Women's Rights and the National Council of Women of Greece also cooperated on getting amendments made to civil law and in connection with prostitution. On February 5, 1930 in Greece, all literate women over the age of 30 were granted the right to vote in municipal elections (Vervenioti, 2000). At that time, Greek women - like women in many other European countries - were also struggling to decide whether it was wiser to run independently or as members of political parties in their attempt to enter into politics. All women's organisations started to realise that it was becoming increasingly difficult for women to be elected without joining an established political party. In fact, in all the countries Brunschvicg visited, most women's organisations struggling for suffrage were strongly in favour of women joining the political parties which shared their views. They encouraged women to gain power within political parties while also remaining committed to their goal and staying above party politics.

After Greece, Brunschvicg visited Turkey for the first time (Brunschvicg, 1933c). She met with the board members of the UTW and engaged in long conversations with them about the current situation of women in the new Republic. Brunschvicg's second trip to Turkey was in April 1935, to participate in the Twelfth Congress of the IAWSEC. We know that the aim of Brunschvicg's trip to Eastern European, Near Eastern and Middle Eastern countries was to attract members for the IAWSEC and to increase the number of delegates to the Istanbul Congress scheduled for $1935^{29}$ (Schreiber and Mathieson, 1955). The fact that Turkey was a Muslim country which had transitioned from an autocratic state structure to a secular-republican one that recognised full civil rights for women attracted the attention of Western European feminists. Although French members of the IAWSEC did not oppose the colonialist policies of France, they believed that Turkey could provide an ideal example for the Muslim women living in the French colonies such as Morocco, Algeria and Tunisia. According to Brunschvicg, Ottoman upper class women who were liberated from some patriarchal traditions constituted a team ready to protect and promote Republican principles. She firmly believed that Muslim women from North African countries could follow the example of women in Turkey.

Brunschvicg discussed with Seniha Rauf how the UTW program prepared Turkish women for Republican citizenship. Rauf cited many examples from the activities undertaken by the UTW, adding that the economic crisis was making their work difficult. She also mentioned that her organisation hosted the IAWSEC conference presided by Emily Rieder. Rauf explained that Efzayiş Suat, responsible for UTW's international relations, had represented the UTW at the Third Balkan Conference in Bucharest in October 1932.

In March 1933 Rauf attended the Marseille Conference ("Alliance Conference at Marseille", 1933) together with Lâmia Refik, another member of the UTW board. The conference, organised by the IAWSEC in Marseille on March 18-22, 1933, can be considered as an intermediate congress. The opening speeches were given by the Mayor of Marseille, by the hosts of the Congress Cécile Brunschvicg and Maria Vérone, and by the president of the IAWSEC Margery Corbett Ashby. Delegates like Huwa Sha'arawi, Seniha Rauf, Ruby Rich Schalit and Dr. Paulina Luisi delivered speeches as well. Mary Laughton Mathews, Princess Cantacuzino, Vera Urbanová and Marie

\footnotetext{
26 Syndesmos gia ta Dikaiomata tis Gynaikas.

${ }^{27}$ L'Oeuvre Patriotique pour la Protection de l'Enfant.

${ }^{28}$ Ligue des Femmes Grecques.

${ }^{29}$ After the Stockholm Congress, the IWSA decided to open up to the East, and Carrie Chapman Catt (1859-1947) and Aletta Jacobs (1854-1929) started a two-year world tour (1911-1913) to promote its principles and to bring new organisations to the IWSA. They went to South Africa, Israel, Syria, Lebanon, Palestine, Egypt, Sri Lanka, India, Burma Island, Cava, the Philippines, China, Canton, Shanghai, Nanjing, Tokyo, and the Hawaiian Islands.
} 
Hjelmer spoke on political rights. On March 20-23, the Peace Commission and the Commission on Moral Equality of IAWSEC held various meetings. Sessions and discussions on women's political rights were held in Montpellier, Nîmes, Avignon, Toulon and Nice, along with touristic trips on 15 to 17 March and 23 to 27 March. At the end of the conference, on 27 March, 1933, a final declaration was made on peace and equality. Besides these international activities, Rauf shared information about additional work by Turkish feminists, such as opening of a dormitory for young girls who came to Istanbul from Anatolia to study ${ }^{30}$, buying school supplies for poor elementary and middle school students, assisting unemployed and young girls to find work, and helping poor people to be admitted to hospital free of charge. According to Brunschvicg's reports, Lâtife Bekir and Lâmia Refik were struggling for the political rights of Turkish women, while Seniha Rauf was in charge of the struggle for peace. Most of the materials Brunschvicg published are reports on the Turkish women she had met during her visit to Istanbul, containing her conversations and observations, rather than in-depth research.

After Turkey, Brunschvicg travelled to Bulgaria. During the visit, she was required to follow the official program designed by the Bulgarian government and was not able to do what she had initially planned. Nevertheless, she was able to meet Ivanova, the president of the Bulgarian Women's Union (BWU), Ekaterina Zlatoustova, the president of the Druzhestvoto na bulgarkite $s$ visshe obrazovanie (Association of Bulgarian Women University Graduates), Tatiana Kirkova, who worked at the Ministry of Foreign Affairs and Maria Bisserova, president of the feminist association in Rousse. Brunschvicg emphasised that BWU envisioned various important activities to enable women to exercise their rights as conscious citizens and get them to know political life more closely (Brunschvicg, 1933d).

The final Balkan country Brunschvicg visited was Romania, where she was a special guest of Princess Cantacuzino (Brunschvicg, 1933e). Brunschvicg represented Cantacuzino as a woman of traditions, progress, nationalism and peace without departing from her high social ideals. Unlike the situation in France, where women of different opinions were organised into separate associations, Romanian women, according to the French feminist, worked together within the National Council of Romanian Women (NCRW).

For Brunschvicg, Cantacuzino's finest accomplishment in the women's movement was the establishment of Casa femeii ('Women's House') ${ }^{31}$. Brunschvicg openly professed her admiration for this institution. She questioned the reason for the lack of a similarly well-organised Women's House in France and hoped that such an institution could be established soon. Brunschvicg met with the leaders of the NCRW at a meeting held at the Casa femeii. The women's council in Romania was struggling to expand the political rights of women (after in 1929 married women with a high school education got the municipal vote), to ensure full equality in civil law, close brothels, provide all kinds of healthcare to women, establish new programs for girls' education, and allow married women to become civil servants. Brunschvicg also offered descriptions of some organisations working for women's suffrage. Among them were the Romanian League for Women's Rights and Responsibilities ${ }^{32}$ founded in 1910 by Eugenia de ReussIanculescu ${ }^{33}$ and Asociația de Emancipare Civilă și Politică a Femeii Române ('The Association for the Civil and Political Emancipation of the Romanian Woman'), established in Iași, 1917 and represented by Botez, Popp, and Elena Meissner (1867-1940).

After visiting these five countries, Brunschvicg returned to Belgrade via the Danube and then back to France, where she wrote her impressions. She noted that the level of organisation of the women's movements in the Balkans was beyond her expectations and in line with the goals of the international women's movement at the time.

\section{CONCLUSION}

The period between 1923 and 1935 was important for the relations between the UTW and various women's movements in Europe and particularly Balkan feminists. Even if they did not have the opportunity to work together in the LEW, they had the chance to work on women's issues between 1930 and 1933 in the Balkan Conferences. After the Istanbul conference of the IAWSEC, the gathering of the IAWSEC in Copenhagen (1939) was the last one before World War II. The UTW was not present there because it was dissolved in 1935.

Although the dissolution of the UTW was on the agenda of the government for a long time, news of the process of closing down the union and 'erasing it' from social life began in the press two weeks after the Twelfth Congress. In one report, an unnamed UTW executive stated that Turkish women were given every right and that it would be wrong to have an association that still puts on its agenda women's rights. In one of her speeches, Lâtife Bekir

\footnotetext{
${ }^{30}$ In Necile Tevfik's private papers, document 46 is a report written in her own handwriting where she explains the purpose of the social projects of the UTW and the newly opened student residence for young girls (Davaz, 2019).

${ }^{31}$ La Casa Femminile.

${ }^{32}$ La Ligue pour les Droits et Devoirs de la Femme en Roumanie.

${ }^{33}$ Romanian suffragist and feminist.
}

(C) 2020 by Author/s 
stated that the decision for the dissolution of the UTW was taken one year before the Twelfth Congress, upon changing the constitution and granting equal rights to men and women. She stated that, since it was decided in advance to convene the Congress in Istanbul, together with the government, they postponed the dissolution to after the Congress. When asked how she would fulfil her role as Vice-President of IAWSEC, she said she would resign from her duty because the UTW would not have any more right of representation after the dissolution.

Although the decision to dissolve had been taken a year before, the question of why she accepted this duty on the last day of the Congress remained unanswered. We do not have enough documents to answer exactly why the UTW executives and members did not object and criticise this decision. But one of a few documents that we have from a member of the UTW writing about the dissolution is a draft article by Necile Tevfik called 'The Last Souvenir of the Union of Turkish Women' (Davaz, 2019) where she stated her disappointment about the dissolution. Another important document about this decision is a letter ${ }^{34}$ written by Necile Tevfik to Rosa Manus where she expressed her sadness and emotionality (Davaz, 2014: 751-754). Although she knew that the UTW which they had been devoted to for a long time would close, she was hoping that everything could change at once with another decision. However, when Atatürk's decision was finalised, they chose to fulfil their commitment to Atatürk at a cost to the feminist cause itself ${ }^{35}$. The UTW activists continued on a personal basis to have relations with the delegates of the Twelfth Congress although they entered a deep silence until 13 April 1949 - the date of the re-opening of the UTW.

\section{ACKNOWLEDGEMENTS}

I would like to thank Adnan Bucak for his contribution to the English version of this article, and to Krassimira Daskalova and Maria Bucur for their critical comments and suggestions.

\section{REFERENCES}

"Alliance Conference at Marseille". (1933, April). Jus Suffragii, 27 (7), pp. 51-52.

"L'activité de nos soeurs roumaines". (1931, Décembre). L'Egyptienne (75), pp. 32-33.

"Première Conférence Balkanique". (1930, Décembre). L'Egyptienne (64), p. 51.

“Première Conférence Balkanique”. (1930, Décembre). L'Egyptienne (64), pp. 53-54.

“Turkey”. (1925, April). Jus Sufragii, 19 (7), pp. 101-102.

“Turquie-Déleguée: Mme. Seniha Rauf”. (1931, July). Jus Suffragii, 25 (10), p. 163.

“Twelfth Congress: Istanbul, 18-25 April, 1935”. (1934, June). Jus Suffragii, 28 (9), p. 1.

[JusSuffragii]. (1935). Jus Suffragii, 29 (7), 52.

Akandere, O. (2004). 20-26 Ekim 1931 Tarihlerinde İstanbul'da Toplanan İkinci Balkan Konferansı ve Sonuçları. Türkiyat Arasstrmalar Dergisi (14), 260-261.

Akandere, O. (2004). 20-26 Ekim 1931 Tarihlerinde İstanbul'da Toplanan İkinci Balkan Konferansı ve Sonuçları. Türkiyat Arastrmalarn Dergisi (14), p. 285.

Akandere, O. (2004). 20-26 Ekim 1931 Tarihlerinde İstanbul'da Toplanan İkinci Balkan Konferansı ve Sonuçları. Türkiyat Arastrmalar Dergisi (14), p. 265.

Boutzouvi, A. (2006). Avra Theodoropoulou. In F. d. Haan, K. Daskalova, \& A. Loutfi (Eds.), A Biographical Dictionary of Women's Movements and Feminisms: Central, Eastern and South Eastern Europe, 19th and 20th Centuries (pp. 569-574). Budapest: Central European University.

Brunschvicg, C. (1933a, Septembre 16). Chez les féministes de l'Europe orientale. La Francaise (1076).

Brunschvicg, C. (1933b, Septembre 23). Chez les féministes de l'Europe orientale. La Française (1077).

Brunschvicg, C. (1933c, Septembre 30). Chez les féministes de l'Europe orientale. La Française (1078).

Brunschvicg, C. (1933d, Octobre 7). Chez les féministes de l'Europe orientale. La Française (1079).

Brunschvicg, C. (1933e, Octobre 14). Chez les féministes de l'Europe orientale. La Française (1080).

Bucur, M. (2006). Calypso Botez (1880-?). In F. d. Haan, K. Daskalova, \& A. Loutfi (Eds.), A Biographical Dictionary of Women's Movements and Feminisms: Central, Eastern and South Eastern Europe, 19th and 20th Centuries (p. 76). Budapest: Central European University Press.

Bucur, M. (2019, June). Nationalism and Feminism in Interwar Romania: Alexandrina Cantacuzino and the Little Entente. Council for European Studies.

Çakır, S. (1994). Osmanl Kadnn Hareketi (1 ed.). İstanbul: Metis Yayınları.

\footnotetext{
${ }^{34}$ Atria: Institute on gender equality and women's history, the letter written by Necile Tevfik to Rosa Manus on the 14th of May 1935 is kept in Rosa Manus Private Papers.

35 Atria Institute on gender equality and women's history, "Mais nous devions accomplir un devoir, un geste de reconnaissance, pendant lequel nous n'avions pas à faiblir.” Necile Tevfik's letter to Rosa Manus is kept in Rosa Manus' Private Papers.
} 
Cheşchebec, R. (2006). Princess Alexandra Cantacuzino. In F. d. Haan, K. Daskalova, \& A. Loutfi (Eds.), A Biographical Dictionary of Women's Movements and Feminisms: Central, Eastern and South Eastern Europe, 19th and 20th Centuries (pp. 89-94). Budapest: Central Eurpean University Press.

Cheşchebec, R. (2006). Toward a Romanian Women's Movement: An Organizational History (1880s-1940). In E. Saurer, M. Lanzinger, \& E. Frysak (Eds.), Women's Movements: Networks and Debates in post-communist Countries in the 19th and 20th Centuries (p. 450). Böhlau.

Daskalova, K. (2004). The women's movement in Bulgaria in a life story. Women's History Review, 13 (1), $91-104$.

Daskalova, K. (2006). Dimitrana Ivanova (1881-1960). In F. d. Haan, K. Daskalova, \& A. Loutfi (Eds.), A Biographical Dictionary of Women's Movements and Feminisms: Central, Eastern and South Eastern Europe, 19th and 20th Centuries (pp. 182-185). Budapest: Central European University Press.

Daskalova, K. (2008). Balkans. (B. G. Smith, Ed.) The Oxford Encyclopedia of Women in World History, 1, pp. $193-195$.

Daskalova, K. (2018). Little Entente of Women/Malkata Zhenska Antanta I feministkite dvizhenia na Balkanite prez 20-te I 30-te godini na XX vek (The Little Entente of Women and the feminist movements in the Balkans during the 1920s and 1930s). Sotsiologicheski problemi [Issues of Sociology] (2), 675-695.

Davaz, A. (2014). Eşitsiz Kız Kardeşlik: Uluslararası ve Ortadoğu Kadın Hareketleri, 1935 Kongresi ve Türk Kadın Birliği (Unequal Sisterhood: International and Middle East Women's Movements, the 1935 Congress and the Union of Turkish Women). İstanbul: Türkiye İş Bankası Kültür Yayınları.

Davaz, A. (2019). Bir Kadın Arşivini Okuma Denemesi: Necile Tevfik Arşivi Açılamalı Kataloğu (1924-1954) ("An Essay" on Reading a Woman's Private Papers: Annotated Catalogue of the Necile Tevfik Private Papers 1924-1954). Istanbul: Türkiye İş Bankası Kültür Yayınları-Kadın Eserleri Kütüphanesi ve Bilgi Merkezi Vakfı.

IIème Conférence Balkanique: İstanbul-Ankara, 19-26 Octobre 1931. (1932). İstanbul.

Ilème Conférence Balkanique: Istanbul-Ankara, 19-26 Octobre 1931. (1932). İstanbul.

Kara, L. (1950). Birleşmiş Milletler Kadın Hakları Komisyonunda Türkiye’yi Temsil Eden Bayan Mihri Pektaş ile Bir Görüşme. Kadın Gazetesi (181), 3.

Popa, R. M. (2006). Eugenia de Reuss Ianculescu (1866-1938). In F. Haan, K. Daskalova, \& A. Loutfi (Eds.), A Biographical Dictionary of Women's Movements and Feminisms: Central, Eastern and South Eastern Europe, 19th and 20th Centuries (pp. 569-573). Budapest: Central European University Press.

Psarra, A. (2007). A Gift from the New World: Greek Feminists between East and West (1880-1930). In A. Frangoudaki, \& Ç. Keyder, Ways to Modernity in Greece and Turkey: Encounters with Europe, 1850-1950 (p. 166). London: I. B. Tauris.

Rauf, S. (1969). Latife Bekir Çeyrekbaşı ve Türk Kadın Birliği [Latife Bekir Çeyrekbaşı and the Union of Turkish Women]. Hayat Tarih Mecmuası (3), 75.

Schreiber, A., \& Mathieson, M. (1955). Journey Towards Freedom: Written for the Golden Jubilee of the International Alliance of Women. Copenhagen: International Alliance of Women.

Tevfik, N. (1935). Femmes turques d'aujourd'hui. La Française (1148), 1.

Verginella, M. (2006). Alojzija Štebi. In F. d. Haan, K. Daskalova, \& A. Loutfi (Eds.), A Biographical Dictionary of Women's Movements and Feminisms: Central, Eastern and South Eastern Europe, 19th and 20th Centuries (pp. 530-533). Budapest: Central European University Press.

Vervenioti, T. (2000). The Adventure of Women's Suffrage in Greece. In C. Duchen, \& I. Bandhauer-Schoffmann (Eds.), When the $W$ ar was Over: $W$ omen, $W$ ar and Peace in Europe, 1940-1956 (p. 103). New York; London: Leicester University Press.

Citation: Davaz, A. (2020). An Annotated Archive of Entangled European Feminist History: The Union of Turkish Women, the Second Balkan Conference and Cécile Brunschvicg's Visit to Balkan Feminists (1923-1935). Feminist Encounters: A Journal of Critical Studies in Culture and Politics, 4(2), 28. https:/ / doi.org/10.20897/femenc/8516

Copyright (C) 2020 by Author/s and Licensed by Lectito BV, Netherlands. This is an open access article distributed under the Creative Commons Attribution License which permits unrestricted use, distribution, and reproduction in any medium, provided the original work is properly cited. 